\title{
Massive proliferation of lens epithelial remnants after Nd-YAG laser capsulotomy
}

University Department of Ophthalmology, Hospital

N P Jones

D McLeod

M E Boulton

Correspondence to: Department of

Ophthalmology, Manchester Royal Eye Hospital, Oxford

Road, Manchester

M139WH.

Accepted for publication 20 October 1994 Manchester Royal Eye Mr N P Jones, University

\begin{abstract}
Eight eyes exhibited massive proliferation of lens epithelial remnants following Nd-YAG posterior capsulotomy. All eyes had pre-existing retinal pathology. Six had undergone vitrectomy (four for proliferative diabetic retinopathy) before extracapsular cataract extraction with posterior chamber intraocular lens implantation. The other two eyes had familial exudative vitreoretinopathy or retinopathy of prematurity, respectively. Five eyes required removal of the lens proliferations via a pars plana approach. High levels of growth factors in the posterior segment associated with proliferative disorders of the retina may play a role in lens cell proliferation.
\end{abstract}

(Br f Ophthalmol 1995; 79: 261-263)

Retention and sequestration of lens epithelial elements (Soemmerring's ring ${ }^{1}$ ) and their subsequent metaplasia and proliferation causes opacification of the posterior lens capsule in up to $50 \%$ of patients ${ }^{23}$ after extracapsular cataract extraction (ECCE) with or without intraocular lens (IOL) implantation. In the majority of such patients, central clearance of the opacification using the neodymiumyttrium/aluminium/garnet (Nd-YAG) laser is straightforward and effective. ${ }^{4}$ It is occasionally complicated by damage to the IOL, ${ }^{5}$ raised intraocular pressure, ${ }^{6}$ cystoid macular oedema,${ }^{7}$ retinal detachment, ${ }^{8}$ or spreading of endocapsular low grade endophthalmitis. ${ }^{9}$ The need for further laser or surgical capsulotomy is rare, though $\mathrm{Holz}$ et $a l^{10}$ described pearl formation following Nd-YAG capsulotomy after removal of a traumatic cataract, requiring further Nd-YAG clearance. We report a series of eight patients, with some features in common, all of whom developed massive proliferation of lens epithelial elements following

Table 1 Summary of the features of eight patients with massive proliferation of lens remnants

\begin{tabular}{|c|c|c|c|c|c|c|c|c|}
\hline & \multicolumn{8}{|l|}{ Case } \\
\hline & 1 & 2 & 3 & 4 & 5 & 6 & 7 & 8 \\
\hline $\begin{array}{l}\text { Sex/age at cataract surgery } \\
\text { Associated pathology } \\
\text { Pre-cataract vitrectomy } \\
\text { (silicone oil injection) } \\
\text { Heparin IOL }\end{array}$ & $\begin{array}{l}\text { M/39 } \\
\text { PDR } \\
\text { Yes } \\
\text { Yes } \\
\text { Yes }\end{array}$ & $\begin{array}{l}\text { F/56 } \\
\text { ARN } \\
\text { Yes } \\
\text { Yes } \\
\text { Yes }\end{array}$ & $\begin{array}{l}\text { F/37 } \\
\text { PDR } \\
\text { Yes } \\
\text { No } \\
\text { Yes }\end{array}$ & $\begin{array}{l}\text { M/56 } \\
\text { ERM } \\
\text { Yes } \\
\text { No } \\
\text { No }\end{array}$ & $\begin{array}{l}\text { M/18 } \\
\text { FEVR } \\
\text { No } \\
\text { No } \\
\text { No }\end{array}$ & $\begin{array}{l}\text { F/59 } \\
\text { PDR } \\
\text { Yes } \\
\text { Yes } \\
\text { Yes }\end{array}$ & $\begin{array}{l}\text { F/42 } \\
\text { ROP } \\
\text { No } \\
\text { No } \\
\text { No }\end{array}$ & $\begin{array}{l}\text { F/48 } \\
\text { PDR } \\
\text { Yes } \\
\text { No } \\
\text { No }\end{array}$ \\
\hline $\begin{array}{l}\text { Interval between Nd-YAG } \\
\text { capsulotomy and observation of } \\
\text { lens proliferation (months) } \\
\text { Surgical corticocapsulectomy }\end{array}$ & $\stackrel{4}{\text { Yes }}$ & $\begin{array}{l}3 \\
\text { No }\end{array}$ & $\begin{array}{l}6 \\
\text { No }\end{array}$ & $\begin{array}{l}12 \\
\text { Yes }\end{array}$ & $\begin{array}{l}18 \\
\text { Yes }\end{array}$ & $\stackrel{9}{\text { Yes }}$ & $\begin{array}{l}8 \\
\text { No }\end{array}$ & $\begin{array}{l}18 \\
\text { Yes }\end{array}$ \\
\hline
\end{tabular}

$A R N=$ acute retinal necrosis; $E R M=$ epiretinal membrane; $F E V R=$ familial exudative

vitreoretinopathy; $\mathrm{PDR}=$ proliferative diabetic retinopathy; $\mathrm{ROP}=$ retinopathy of prematurity
Nd-YAG capsulotomy, and discuss the possible cause of this phenomenon.

\section{Patients and methods}

Eight patients who had earlier undergone ECCE + IOL followed by Nd-YAG capsulotomy, went on to develop massive proliferation of lens epithelial remnants. The associated clinical features, previous surgery, and the further surgical interventions required were reviewed.

\section{Results}

All eight patients had associated posterior segment problems. Four had proliferative diabetic retinopathy (PDR) while the remainder had each presented with acute retinal necrosis, idiopathic vitreous haemorrhage with a fibrocellular epimacular membrane, familial exudative vitreoretinopathy, or the late sequelae of retinopathy of prematurity (ROP) (Table 1). Vitrectomy had been undertaken in six eyes before cataract surgery; in three of these, silicone oil had been injected and had subsequently been removed before ECCE+IOL (Table 1). The four vitrectomised diabetics with massive lens proliferation represent a small minority of the patients under our care who have undergone phakic diabetic vitrectomy followed by ECCE+IOL and later Nd-YAG capsulotomy. One of the two patients in whom vitrectomy had not been undertaken had nevertheless undergone (in both eyes) encirclement and cryotherapy for progressive tractional sequelae of ROP before ECCE+IOL and subsequent Nd-YAG capsulotomy (case 7); massive lens proliferation developed in only one of the eyes so treated.

In all eight eyes ECCE+IOL had been uneventful. In four, a heparin surface modified IOL had been implanted. Nd-YAG capsulotomy was followed in all eight eyes by massive capsule proliferation, maximal at the edges of the capsulotomy. There was no associated rubeosis in any of the eyes at this stage. In two eyes the capsulotomy was wide and the visual axis was unaffected, but six required further capsule management. In three, further Nd-YAG capsulotomy was attempted but in only one case (case 3 ) was this successful. The bulbous, gelatinous nature of the globular proliferations was consistent between patients as was the ability to absorb Nd-YAG energy without disruption. Five patients ultimately required surgical corticocapsulectomy via the pars plana (Table 1). We include three illustrative case reports: 
CASE 1

A 38-year-old insulin dependent diabetic of 23 years standing presented with bilateral severe PDR. In his left eye, surgical treatment was unsuccessful. In the right eye, an extramacular tractional retinal detachment from severe fibrovascular proliferation slowly progressed though the visual acuity was $6 / 6$. The eye underwent vitrectomy, membrane delamination, endolaser, and sulphur hexafluoride gas $\left(\mathrm{SF}_{6}\right)$ injection. One month later a further procedure was necessary, including a further delamination, endolaser, encirclement and buckling, and silicone oil injection. Three months later the silicone oil was removed. The development of a cataract led to ECCE with implantation of a heparin surface modified posterior chamber IOL. A visual acuity of $6 / 9$ was achieved. Deterioration of vision due to posterior capsular opacification was treated by Nd-YAG laser capsulotomy 5 months later. A visual acuity of $6 / 6$ was only temporary owing to the development of massive lens/capsule 'pearls', encroaching on the visual axis. Further Nd-YAG laser treatment was again temporarily successful but a third treatment was ineffective owing to the apparently gelatinous nature of the material, with poor laser uptake. Pars plana corticocapsulectomy was therefore performed. The patient maintained a visual acuity of $6 / 62$ years later.

\section{CASE 2}

A 55-year-old woman presented with unilateral ocular discomfort and deterioration of vision to hand movements owing to acute retinal necrosis with combined tractional and rhegmatogenous retinal detachment.

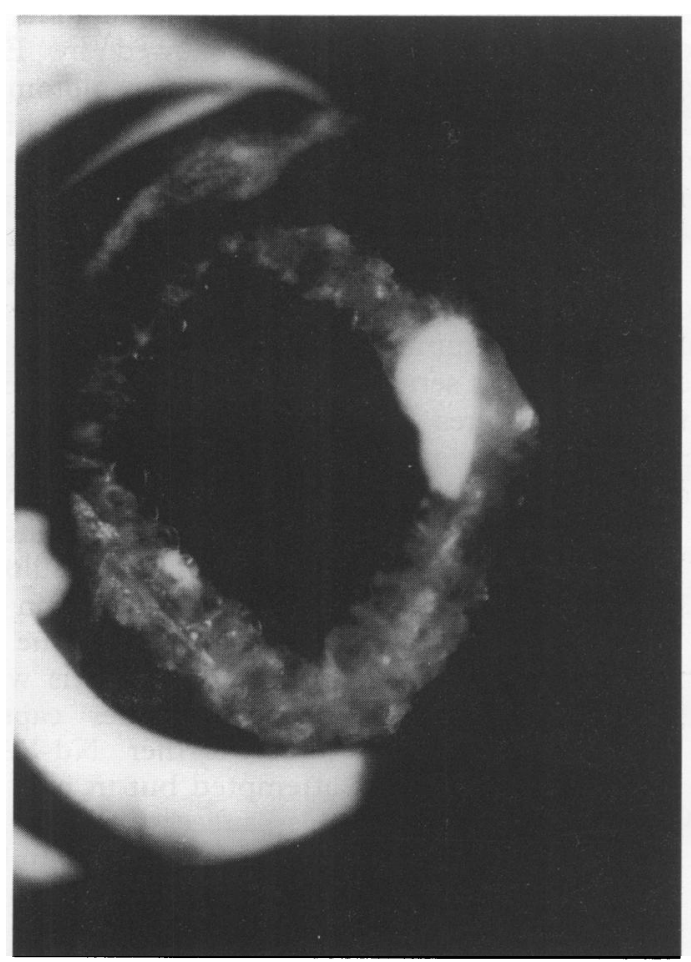

Figure $1 A$ 'doughnut' of coalescent globular lens epithelial remnants around the edge of a previous $N d-Y A G$ capsulotomy. Surgical corticocapsulectomy has been unnecessary (case 2).
Vitrectomy was performed, including retinotomy, internal drainage, silicone oil injection, endolaser, and encirclement. Three months later the silicone oil and a macular epiretinal membrane were removed and further endolaser applied. The retina remained attached and a visual acuity of $6 / 18$ was attained. Sixteen months later, following visual loss to counting fingers, ECCE and IOL implantation (heparin surface-modified) was performed uneventfully, and a visual acuity of $6 / 18$ was regained. Ten months later Nd-YAG posterior capsulotomy was necessary. Proliferation of lens remnants occurred but the capsulotomy was sufficiently wide that the visual axis was uninvolved (Fig 1). A visual acuity of $6 / 18$, owing to cystoid macular oedema (which has been present before the capsulotomy was performed), was maintained 1 year later.

\section{CASE 3}

A 36-year-old insulin dependent diabetic of 32 years' standing presented with bilateral severe PDR. The right eye, treated by vitrectomy, membrane segmentation, and endolaser photocoagulation retained a visual acuity of $6 / 18$. The left eye had rubeosis and a combined tractional and rhegmatogenous retinal detachment, and underwent vitrectomy, membrane delamination, internal drainage of subretinal fluid, encirclement, endolaser photocoagulation, and intraocular gas $\left(\mathrm{SF}_{6}\right)$ injection. An initially satisfactory result was followed by the development of cataract. Two years after vitrectomy, ECCE was performed with insertion of a heparin surface modified posterior chamber IOL. Visual acuity, initially recovering to $6 / 9$, then deteriorated owing to posterior capsule opacification. Nd-YAG laser capsulotomy was followed by massive proliferation of lens epithelial remnants, encroaching upon the visual axis. This material was partially cleared by further Nd-YAG laser treatment, and although remnants persisted, there was a functionally clear visual axis and a visual acuity of $6 / 9$ a year later.

\section{Discussion}

Massive proliferation of lens epithelial remnants after Nd-YAG capsulotomy has, to our knowledge, been described in only one patient, ${ }^{10}$ and has not been reported in patients with PDR, including those who had previously undergone vitrectomy. ${ }^{1112}$ In this series of patients, massive proliferation of lens remnants occurred within months of the capsulotomy, reducing or closing the capsular aperture and sometimes reducing vision. All patients had had posterior segment pathology including epiretinal proliferations whether fibrovascular or fibrocellular.

We postulate a role for growth factors in the initiation and perpetuation of the lens cell proliferation. It is well documented that vitreous aspirates from patients with PDR or proliferative vitreoretinopathy have significant mitogenic activity compared with control 
vitreous ${ }^{13-15}$; elevated levels of potent mitogenic factors such as basic fibroblast growth factor, ${ }^{16}$ insulin-like growth factor $I,{ }^{17}$ and platelet derived growth factor ${ }^{18}$ have been identified. In vitro studies have shown that lens epithelial cell proliferation is stimulated by these factors, ${ }^{19}$ and indirect evidence for an in vivo effect is provided by the finding of increased lens size in insulin dependent diabetes. ${ }^{20}$ It is plausible that it is these or other growth factors which induced the massive proliferation of lens cells in our patients. That such growth factors are present, and are prevented from reaching the anterior segment by an intact posterior capsule, is said to account for the increased incidence of iris rubeosis in diabetics after intracapsularcataract surgery or posterior capsulotomy. ${ }^{1121}$ Furthermore, the lens capsule, rather than simply being a barrier, may act as a 'sponge' for growth factors of retinal origin ${ }^{22}$ and this could lead to an increased concentration of these molecules in the region of the posterior capsule.

Disruption of the posterior capsule by the $\mathrm{Nd}-\mathrm{YAG}$ laser could act in one or more of a number of different ways to promote lens proliferation. Firstly, disruption of the capsular bag may result in mitogen containing fluid from the posterior segment bathing the lens epithelial remnants. Secondly, the laser may directly provoke cellular proliferation, a phenomenon observed following Nd-YAG laser to trabecular meshwork cells. ${ }^{23}$ Thirdly, the Nd-YAG laser may 'activate' lens epithelial cells to produce proteolytic enzymes capable of releasing otherwise inactive growth factors bound to matrix molecules in the remaining capsule. However, we do not believe that Nd-YAG capsulotomy is an essential prerequisite for such lens proliferation. Another two insulin dependent diabetics under our care developed gross lens proliferation causing wide separation of the IOL from an intact posterior lens capsule following vitrectomy and ECCE+IOL.

Our patients had complex eye problems, often requiring more than one operation. The need for further surgical intervention in the form of corticocapsulectomy was therefore unfortunate, though there were no untoward sequelae. Maximisation of cell clearance from the posterior capsule during cataract surgery is advocated, though the technical difficulty of dealing with the capsule after previous vitrectomy is an important consideration. If required, a particularly large Nd-YAG capsulotomy should be performed in such patients so that, even should massive proliferation occur, there is less chance of involvement of the visual axis.

1 Soemmerring D. Beobachtungen ueber die organischen Veraenderungen des Auges nach Staaroperationen. Frankfurt/a/M, Wesche, 1828

2 Apple DJ, Solomon KD, Tetz MR, Assia EI, Holland EY, Legler UFC, et al. Posterior capsule opacification. Surv Ophthalmol 1992; 37: 73-115.

3 Sterling S, Wood T. Effect of intraocular lens convexity on posterior capsule opacification. F Cataract Refract Surg 1986; 12: 655-7.

4 Shah G, Gills J, Durham D, Ausmus W. Three thousand YAG lasers in posterior capsulotomies: an analysis of complications and comparison to polishing and surgical complications and comparison to polishing
discission. Ophthalmic Surg 1986; 17: 473-7.

5 Bath P, Boerner C, Dang Y. Pathology and physics of YAGlaser intraocular lens damage. F Cataract Refract Surg 1987; 13: 47-9.

6 Channell $M$, Beckman $H$. Intraocular pressure changes after neodymium-YAG laser posterior capsulotomy. Arch Ophthalmol 1984; 102: 1024-6.

7 Lewis H, Singer T, Hanscom T, Strattsma B. A prospective study of cystoid macular oedema after neodymium:YAG laser posterior capsulotomy. Ophthalmology 1987; 94: laser poste.

8 Rickman-Barger L, Florine C, Larson R, Lindstrom R. Retinal detachment after neodymium:YAG laser posterior capsulotomy. Am f Ophthalmol 1989; 107: 531-6.

9 Tetz M, Apple D, Price FJ. A newly described complication of neodymium:YAG laser capsulotomy: exacerbation of an intraocular infection. Arch Ophthalmol 1987; 105: $1324-5$.

10 Holz FG, Tetz M, Völcker HE. Extrakapsuläre kataraktextraktion mit hinterkammerlinsenimplantation beiumschrieber In: Wenzel M, Reim M, Freyler H, Hartmann C, eds Kongress der Deutschen Gesellschaft für INtraokularlinsen

1 Ruiz RS, Saatci OA. Posterior chamber intraocular lens implantation in eyes with inactive and active proliferative diabetic retinopathy. Am $f$ Ophthalmol 1991; 111: 158-62.

2 Benson WE, Brown GC, Tasman W, McNamara JA, Vander JF. Extracapsular cataract extraction with placement of a posterior chamber lens in patients with diabetic retinopathy. Ophthalmology 1993; 100: 730-8.

13 Boulton ME, McLeod D, Garner A. Vasoproliferative retinopathies: clinical, morphogenetic and modulatory retinopathies: clinical, morphogenetic
aspects. Eye $1988 ; 2$ (suppl): S124-39.

14 Lutty GA, Chandler C, Bennett A, Fait C, Patz A. Presence of endothelial cell growth factor activity in normal and of endothelial cell growth factor activity in
diabetic vitreous. Curr Eye Res 1986; 5: 6-17.

15 Boulton ME, Moriarty P, Gregor ZJ. Biological activities of vitreous gel, retrohyaloid fluid and subretinal fluid from diabetic and non-diabetic eyes. Br $\mathcal{F}$ Ophthalmol 1992; 76: $79-83$.

16 Sivalingham A, Kenney J, Brown GC, Benson WE, Donoso L. Basic fibroblast growth factor levels in the vitreous with proliferative diabetic retinopathy. Arch Ophthalmol 1990; 108: 869-72.

17 Grant MB, Russell B, Fitzgerald C, Merimee TJ. Insulinlike growth factor in the vitreous. Diabetes 1986; 35: like grow 64 .

18 Campochiaro PA, Jerdan JA, Glaser BM, Cardin A, Michels RG. Vitreous aspirated from patients with proliferative vitreoretinopathy stimulate retinal pigmen epithelium cell migration. Arch Ophthalmol 1985; 103: 1403-5.

19 McAvoy JW, Chamberlain CG. Growth factors in the eye. Progress in Growth Factor Research 1990; 2: 29-43.

20 Sparrow JM, Bron AJ, Phelps Brown NA, Neil HAW. Biometry of the crystalline lens in early-onset diabetes. Br $\mathcal{F}$ Ophthalmol 1990; 74: 654-60.

21 Moffat K, Blumenkranz MS, Hernandez E. The lens capsule and rubeosis iridis: an angiographic study. Can f Ophthalmol 1984; 19: 130-3.

22 Glaser BM. Extracellular modulating factors and the control of intraocular neovascularisation. Arch Ophthalmo 1988; 106: 603-7.

23 Dueker DK, Norberg $M$, Johnson DH, Tschumper RC, Feeney-Burns L. Stimulation of cell division by argon and Nd-YAG laser trabeculoplasty in cynomolgus monkeys. Invest Ophthalmol Vis Sci 1990; 31: 115-24. 